\title{
Synergistic interactions of locust bean gum with whey proteins: Effect on physicochemical and microstructural properties of whey protein-based films
}

\author{
K.S. Silva ${ }^{\text {a, b, * }}$, M.A. Mauro ${ }^{\text {b }}$, M.P. Gonçalves ${ }^{\text {a }}$, C.M.R. Rocha ${ }^{\text {a, }}{ }^{* *}$ \\ ${ }^{a}$ REQUIMTE, LAQV, Departamento de Engenharia Química, Faculdade de Engenharia, Universidade do Porto, Rua Dr. Roberto Frias, $4200-465$ Porto, \\ Portugal \\ ${ }^{\mathrm{b}}$ Department of Food Engineering and Technology, Institute of Biosciences, Language and Physical Sciences (IBILCE), UNESP - São Paulo State University, \\ Rua Cristóvão Colombo 2265, 15054-000, São José do Rio Preto, SP, Brazil
}

\section{A R T I C L E I N F O}

\section{Article history:}

Received 20 March 2015

Received in revised form

7 September 2015

Accepted 30 September 2015

Available online 9 October 2015

\section{Keywords:}

Whey protein isolate

Locust bean gum

Edible films

Biopolymer interactions

Film properties

\begin{abstract}
A B S T R A C T
Locust bean gum synergistic interactions with whey proteins are widely described in terms of functional properties. The aim of this work is to assess how these interactions affect whey protein-based film properties. Blended films were manufactured using whey protein isolate (WPI), four different concentrations levels of locust bean gum (LBG) and two different thermal treatments. A rheological study was performed to assess interaction between WPI and LBG. The influence of glycerol on WPI/LBG interactions was also verified. Barrier, mechanical, and optical properties, as well as microstructure, solubility and moisture sorption behavior of films were evaluated. The results show that interaction between WPI and LBG and more severe heat treatments provide stronger, more flexible and less soluble films with lower permeability to carbon dioxide and oxygen and lower transparency. These findings suggest that the addition of locust bean gum to WPI can be used to tune the properties of WPI-based edible films to meet specific food packaging and edible coating needs.
\end{abstract}

() 2015 Published by Elsevier Ltd.

\section{Introduction}

Plastics have been increasingly used as packaging materials all over the world. However, due to their non-biodegradability, the interest in packaging from biodegradable biopolymers has been growing in the last years. Proteins (such as caseinates, gelatin, whey protein) and polysaccharides (starch, chitosan, galactomannans and pectin) are biopolymers widely studied because they usually present good adherence to fruits and vegetables surfaces and good barrier properties to gases such as oxygen and carbonic gas (Han \& Gennadios, 2005). These biopolymers are presented as possible substitutes in petrochemical-based packaging for specific applications.

Whey protein isolates and concentrates result from the

\footnotetext{
* Corresponding author. REQUIMTE, LAQV, Departamento de Engenharia Química, Faculdade de Engenharia, Universidade do Porto, Rua Dr. Roberto Frias, 4200 465 Porto, Portugal.

** Corresponding author.

E-mail addresses: keilasouzas@yahoo.com.br (K.S. Silva), cmrocha@fe.up.pt (C.M.R. Rocha).
}

industrial separation of the protein fraction from whey and are byproducts of cheese manufacture with excellent functional properties. The functionality and performance of edible films depends on their barrier and mechanical properties (Cerqueira et al., 2011). Edible films from whey protein isolates have shown good oxygen and aroma barriers but generally show poor mechanical properties (Hong \& Krochta, 2006; Pérez-Gago \& Krochta, 2002). A minimal content of plasticizer like glycerol is needed to reduce brittleness of the protein-based films, increasing extensibility of film (Gounga, Xu, \& Wang, 2007; Ozdemir \& Floros, 2008). Kokoszka, Debeaufort, Lenart, and Voilley (2010) studied the influence of different glycerol concentrations (30, 40 and $60 \%(w / w)$, of WPI) in films from whey protein isolate (WPI) and observed that film barrier properties are better with $40 \%$ (w/w, of WPI) of glycerol. Whey proteins have an amphiphilic character. This feature allows them to interact with different kind of molecules. It is thus possible to modify the functional properties of whey proteins by the addition of other components, such as polysaccharides (Rocha, Teixeira, Hilliou, Sampaio, \& Gonçalves, 2009). In contrast to casein, WPI is a globular protein with hydrophobic and thiol groups located inside the globular structure. The denaturation, caused by heat treatment, 
opens the globular structure of protein, exposes sulfhydryl and hydrophobic groups that can interact with other molecules and form strong covalent dissulfide intermolecular bonds (Nicolai, Britten, \& Schmitt, 2011).

Galactomannans are heterogeneous polysaccharides commonly used in the food industry, mostly obtained from the endosperm of dicotyledonous seeds of numerous plants. Galactomannans present the advantage of forming viscous solutions at relatively low concentration and being little affected by $\mathrm{pH}$, heat and ionic strength (Cerqueira et al., 2011; Dakia, Blecker, Robert, Wathelet, \& Paquot, 2008; Goycoolea, Morris, \& Gidley, 1995; Sittikijyothin, Torres, \& Gonçalves, 2005). Locust bean gum (LBG) is a kind of galactomannan, also known as carob gum, found in the endosperm of fruit pod of the carob tree, compatible with others gums, thickening agents and proteins, usually used to increase the elasticity and strength of the gel (Barak \& Mudgil, 2014; Fernandes, Gonçalves, \& Doublier, 1991; Gonçalves, Sittikijyothin, Silva, \& Lefebvre, 2004). LBG is partially soluble in water at ambient temperature, however the heat is necessary to achieve best water binding capacity (Maier, Anderson, Karl, Magnuson, \& Whistler, 1993; Pollard \& Fischer, 2006).

Edible films from LBG present high water vapor permeability and elongation-at break values range similar to cellophane films, being indicated by some authors as alternatives to synthetic materials (Bozdemir \& Tutas, 2003; Cerqueira, Souza, Teixeira, \& Vicente, 2012).

Mixtures of whey protein and anionic polysaccharides had presented positive effects on functional properties of gels (Baeza, Sanchez, Pilosof, \& Patino, 2005; Beaulieu, Turgeon, \& Doublier, 2001; Ibanoglu, 2002; Ibanoglu, 2005; Neirynck et al., 2007; Sun, Gunasekaran, \& Richards, 2007). Interaction between whey proteins and galactomannans have also been referred. For instance, Rocha et al. (2009) found interaction between whey protein concentrate (WPC) and locust bean gum (LBG) at pH 7.0 and observed that a small amount of LBG in the presence of salt leads to a big enhancement in the gel strength. Several authors have been studied blends of proteins and polysaccharides as edible film forming agents in order to increase the mechanicals and barrier properties (Arvanitoyannis \& Biliaderis, 1998; Arvanitoyannis, Psomiadou, \& Nakayama, 1996; Arvanitoyannis, Psomiadou, Nakayama, Aiba, \& Yamamoto, 1997; Lee, Park, Lee, \& Choi, 2003; Osés et al., 2009). However, though several authors have studied edible films containing WPI with promising results (e.g. Pierro, Sorrentino, Mariniello, Valeria, \& Porta, 2011; Pereira, Souza, Cerqueira, Teixeira, \& Vicente, 2010; Ramos, Fernandes, Silva, Pintado, \& Malcata, 2012; Seydim \& Sarikus, 2006), few have reported on polysaccharide/whey protein blended films (e.g. Brindle \& Krochta, 2008; Coughlan, Shaw, Kerry, \& Kerry, 2004; Yoo \& Krochta, 2011) and, to best of our knowledge, no investigation was performed about properties of edible films containing WPI and locust bean gum.

This study aims to evaluate the effect of LBG addition on barrier, optical and mechanical properties, microstructure, solubility and sorption isotherms of whey protein isolate (WPI) films. A preliminary rheological study was performed at $\mathrm{pH} 7.0$ to assess if the WPI/LBG interactions persist upon the addition of glycerol (the most common plasticizer used in the WPI-based film formulation). Films were prepared without or with two different LBG amounts and two different thermal treatments, at $\mathrm{pH}$ 7.0.

\section{Materials and methods}

\subsection{Materials}

Whey Protein Isolate (WPI), LACPRODAN DI-9224, kindly supplied by Arla Foods Ingredients (Viby, Denmark), was used as the protein source. This isolate contains a minimum of $93.5 \%$ total protein content (74\% $\alpha$-lactoglobulin, 18\% $\beta$-lactalbumin and 6\% bovine serum albumin), maximum content of $0.2 \%$ lactose and fat, approximately $0.5 \%$ sodium, $1 \%$ of potassium and $0.1 \%$ calcium, as specified by Arla Foods Ingredients.

Locust bean gum (LBG) (>75\% galactomannan content) was kindly supplied by Danisco Portugal (Faro, Portugal).

Glycerol was supplied by Merck (Germany) and other chemicals were supplied by Sigma, Co (St. Louis MO, USA).

\subsection{WPI/LBG solutions}

The stock solution of $1 \%(w / w)$ LBG was prepared by stirring the appropriate amount of dry LBG powder dispersed in distilled water for $1 \mathrm{~h}$, at room temperature. After that, the solution was heated with stirring, for $30 \mathrm{~min}$ at $80^{\circ} \mathrm{C}$. After cooling, the non-dissolved material was removed by centrifugation at $20,000 \mathrm{~g}$ for $30 \mathrm{~min}$. The final concentration was determined from dry matter content.

WPI mixed solutions were prepared by weighing the appropriate amount of WPI powder, adding the required amounts of LBG stock solution, glycerol (used as plasticizer) and $\mathrm{NaCl}$ solution $(20 \%$ $\mathrm{w} / \mathrm{w}$ ) to a final salt concentration of approximately $50 \mathrm{mM}$ to ensure constant ionic strength, and completing to the final volume with distilled water. The mixtures were stirred again during $2 \mathrm{~h}$, at room temperature. The $\mathrm{pH}$ was then adjusted to 7.0 with $\mathrm{NaOH} 1 \mathrm{M}$ and the solution was stirred for $2 \mathrm{~h}$ more.

\subsection{Rheological measurements}

The films can be formed through different mechanisms including coacervation and gelation followed by solvent evaporation. WPI denaturate upon heating and gel which is the usual mechanism used for producing WPI films through solvent casting. Flow would interfere with the gelling mechanism and would impose severe damage to the sample. Therefore, small amplitude oscillation tests were chosen to study the gel formation process, which is important for the film formation. Mixtures of WPI $(10 \% \mathrm{w} /$ $\mathrm{w})$ and $\operatorname{LBG}(0,0.05,0.1,0.2,0.3,0.4$ and $0.5 \% \mathrm{w} / \mathrm{w})$ were prepared for rheological characterization with or without glycerol as plasticizer. For the mixtures with plasticizer, glycerol was added until a final concentration of $4 \%(w / w)$ in the solution. Measurements were performed with a controlled stress rheometer AR-G2 (TA Instruments, New Castle, USA) fitted with parallel-plate geometry (40 mm diameter, gap $800 \mu \mathrm{m}$ ). The mixture was poured onto the plate of the rheometer and covered with paraffin oil to prevent water loss. Samples were heated to $80^{\circ} \mathrm{C}$, at the rate of $2{ }^{\circ} \mathrm{C} / \mathrm{min}$, equilibrated for $3 \mathrm{~h}$ at $80^{\circ} \mathrm{C}$ and cooled from $80^{\circ} \mathrm{C}$ to $20^{\circ} \mathrm{C}$ with the same rate of $2{ }^{\circ} \mathrm{C} / \mathrm{min}$. Mixtures were then equilibrated for $30 \mathrm{~min}$ at $20{ }^{\circ} \mathrm{C}$ to obtain non time dependent dynamic shear modules. Frequency of $1 \mathrm{~Hz}$ was maintained constant and all experiments were performed in the linear viscoelastic region (previously tested) using a target strain of $0.5 \%$.

The experiments were carried out in triplicate with the results reported as the measurements averages.

\subsection{Film preparation}

Solutions were prepared as described above, being the final concentrations in the film forming solutions $5 \%(\mathrm{w} / \mathrm{w})$ for WPI and $2 \%(w / w)$ for glycerol. Four different LBG concentration $(0,0.025$, $0.05 \%$ and $0.1 \%$ ) were tested. After the $4 \mathrm{~h}$ stirring period, the mixtures were heated to denature the protein fraction. Two different heat treatments were used: 1 ) the mixtures were heated until $75{ }^{\circ} \mathrm{C}$ and immediately cooled back to room temperature; 2 ) 
the mixtures were heated until $75^{\circ} \mathrm{C}$, kept at $75^{\circ} \mathrm{C}$ for $10 \mathrm{~min}$ and then cooled back to room temperature.

Films were formed by pouring $28 \mathrm{~g}$ of each film forming solution over disposable polyethylene Petri dishes $(8.6 \mathrm{~cm}$ in diameter). Films were dried in a climate chamber (KBF115, Binder) for $12 \mathrm{~h}$ at $50 \pm 1 \%$ relative humidity $(\mathrm{RH})$ and $35 \pm 2{ }^{\circ} \mathrm{C}$. Afterward, the dried films were equilibrated in desiccator at $53 \%$ relative humidity $(\mathrm{RH})$ and $25{ }^{\circ} \mathrm{C}$ for one week in order to carry out the analyses.

\subsection{Characterization of WPI + LBG films}

\subsubsection{Film thickness}

The thickness of the films was measured at 10 different points for each film using a digital micrometer (Mitutoyo, Japan).

\subsubsection{Mechanical properties}

Mechanical properties, tensile strength (TS) and elongation-atbreak $(E)$, were measured with a texture analyzer (TA.XT2, Stable Micro Systems, Surrey, UK) equipped with tensile test attachments following the guidelines of ASTM D882-91 (ASTM D882-91, 1991) standard method. The initial grip separation was set at $30 \mathrm{~mm}$ and

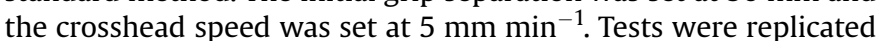
eight times for each type of film. The tests were performed at $25^{\circ} \mathrm{C}$.

\subsubsection{Water vapor permeability measurement}

The measurement of water vapor permeability (WVP) was performed gravimetrically based on ASTM E96-95 method (ASTM E96-95, 1995). The film was sealed on the top of a permeation cell containing calcium chloride $(2 \% \mathrm{RH})$, placed in a desiccator at $25{ }^{\circ} \mathrm{C}$ containing water $(100 \% \mathrm{RH})$ and a miniature fan inside (for constant air circulation). The cells was weighed at intervals of $1 \mathrm{~h}$ during $9 \mathrm{~h}$ using a balance with a resolution of $0.01 \mathrm{mg}$. The slope of weight gain versus time was obtained by linear regression. Three replicates were performed for each film formulation. The WVP was estimated using regression analysis from Eq. (1) as described in literature (McHugh, Avena-Bustillos, \& Krochta, 1993):

$W V P=\frac{\Delta m \cdot x}{A \cdot \Delta t \cdot \Delta P}$

where $\Delta m$ is the weight gain ( $\mathrm{g}$ ) of the test cell, $x$ is the film thickness $(\mathrm{m}), A$ is the permeation area $\left(0.005524 \mathrm{~m}^{2}\right), \Delta t$ is duration (s), $\Delta P$ is the difference of the water vapor partial pressure at $20{ }^{\circ} \mathrm{C}(2337 \mathrm{~Pa})$ across the two sides of the film.

\subsubsection{Water solubility}

Solubility $(S)$ is defined as the content of dry matter solubilized after $24 \mathrm{~h}$ (Cerqueira et al., 2012). The film solubility in water was determined according to the method reported in the literature (Cuq, Gontard, Cuq, \& Guilbert, 1996). Disks (2 cm diameter) cut from the dried films were weighted $\left(W_{0}\right)$ on a Sartorius BP211D balance (Sartorius AG, Germany) and immersed in $50 \mathrm{~mL}$ of water at $25{ }^{\circ} \mathrm{C}$, with agitation (60 rpm). After $24 \mathrm{~h}$, disks were taken out and dried in an oven at $105{ }^{\circ} \mathrm{C}$ until constant weight $\left(W_{f}\right)$. The solubility was determined according to Eq. (2).

$S=\frac{W_{0}-W_{f}}{W_{0}} \times 100$

\subsubsection{Oxygen and carbon dioxide permeability measurement}

Oxygen permeability $\left(\mathrm{O}_{2} \mathrm{P}\right)$ and carbon dioxide permeability $\left(\mathrm{CO}_{2} \mathrm{P}\right)$ were determined based on ASTM D3985-02 standard test method (ASTM D3985-02, 2002). The films were sealed between two chambers and the exposed-film area was $0.0046 \mathrm{~m}^{2}$. Oxygen or carbon dioxide was purged into the lower chamber, while nitrogen was purged into the upper chamber. The flow rate was controlled to maintain the pressure constant (1 atm) in both chambers. Nitrogen acted as a carrier for the $\mathrm{O}_{2}$ (or the $\mathrm{CO}_{2}$ ) crossing the film. The values for $\mathrm{O}_{2} \mathrm{P}$ and $\mathrm{CO}_{2} \mathrm{P}$ were determined by gas chromatography (Chrompack 9001, Middelburg, Netherlands) at $110{ }^{\circ} \mathrm{C}$ and with a molecular sieve $5 \AA 80 / 100$ mesh $1 \mathrm{~m} \times 1 / 8^{\prime \prime} \times 2 \mathrm{~mm}$ column to separate $\mathrm{O}_{2}$, and a Porapak Q 80/100 mesh $2 \mathrm{~m} \times 1 / 8^{\prime \prime} \times 2 \mathrm{~mm} \mathrm{SS}$ column to separate $\mathrm{CO}_{2}$, using a thermal conductivity detector at a $110^{\circ} \mathrm{C}$. Helium was used as carrier gas. A mixture containing $10 \%(\mathrm{v} /$ v) $\mathrm{CO}_{2}, 20 \%(\mathrm{v} / \mathrm{v}) \mathrm{O}_{2}$, and $70 \%(\mathrm{v} / \mathrm{v}) \mathrm{N}_{2}$ was used as the standard for calibration. Three replicates were obtained for each formulation. For each replicate three measurements were taken, after the achievement of the stationary state.

\subsubsection{Moisture sorption isotherms}

Sorption isotherms were plotted for pieces of films $(30 \times 30 \mathrm{~mm})$, based on the static gravimetrical methods proposed by Jowitt et al. (1987). Eight saturated aqueous salt solutions were prepared corresponding to water activity intervals between 0.11 and $0.90\left(\mathrm{LiCl}-0.11 ; \mathrm{MgCl}_{2}-0.33 ; \mathrm{Mg}\left(\mathrm{NO}_{3}\right)_{2}-0.53 ; \mathrm{NaBr}-0.58\right.$; $\left.\mathrm{SrCl}_{2}-0.71 ; \mathrm{NaCl}-0.75 ; \mathrm{KCl}-0.84 ; \mathrm{BaCl}_{2}-0.90\right)$ and placed in small jars. Duplicate samples were weighed for each value of water activity and placed on tripods into the jars, which were then tightly closed and placed in a temperature-controlled chamber maintained at $25{ }^{\circ} \mathrm{C}$. Samples were weighed periodically until they reached constant weight. Dry weights of the samples were determined by the gravimetric method, in triplicate, drying to constant weight in a vacuum oven at $60{ }^{\circ} \mathrm{C}$. For the mathematical description of sorption isotherms the Guggenheim-Anderson-de-Boer (GAB) model (Eq. (3)) (Van den Berg \& Bruin, 1981) was adjusted to the experimental data using the non-linear regression module of Statistica 7.0 software (Statsoft, Tulsa, OK, USA).

$X=\frac{X m \cdot C \cdot K \cdot a_{w}}{\left(1-K \cdot a_{w}\right)\left(1-K \cdot a_{w}+C \cdot K \cdot a_{w}\right)}$

where, $a_{w}$ - water activity, dimensionless; $X$ - equilibrium moisture content (\% dry basis); $X_{m}-$ moisture content of monolayer $(\%$ dry basis) (water content corresponding to saturation of all primary adsorption sites by one water molecule); $C$ - Guggenheim constant and $K$ - corrective constant (Van den Berg \& Bruin, 1981).

The goodness of fit of the models was evaluated using the regression coefficient $\left(R^{2}\right)$. For each setting, the Residual Root Mean Squares (RRMS) were calculated, defined by:

$\operatorname{RRMS}(\%)=100\left\{1 /(n-p-1) \sum_{1}^{n}\left[\left(x^{\exp }-x^{\text {calc }}\right) / x^{\exp }\right]^{2}\right\}^{1 / 2}$

where $x^{\text {exp }}-x^{\text {calc }}$ is the residual [the difference between the experimental $\left(x^{\text {exp }}\right)$ and calculated ( $\left.x^{\text {calc }}\right)$ values]; $n$ is the number of observations, or residuals; $p$ is the number of the fitting parameters and $(n-p)$ defines the degrees of freedom (Daniel \& Wood, 1980).

\subsubsection{Optical properties}

The visible and ultraviolet (UV) light barrier properties of the dried films were measured using an UV-visible Unicam spectrometer model Helios Alpha. WPI films were cut into pieces $(4 \times 1 \mathrm{~cm})$ and attached to a quartz colorimetric cell. Wavelengths from 190 to $700 \mathrm{~nm}$ were selected to measure transmittance and absorbance.

\subsubsection{Microstructure}

Film microstructures were studied by Scanning Electron 
Microscopy (SEM) at CEMUP, Porto, Portugal. The dried samples were coated with a sputtered Au-Pd thin film and analyzed in a Type FEI Quanta 400 FEG SEM under high vacuum using an accelerating voltage of $5 \mathrm{kV}$ and working distances (WD) between 9.5 and $10.5 \mathrm{~mm}$.

\subsubsection{Statistical analyses}

All statistical analyses on the films' properties were made using the Statistica software version 7.0 (StatSoft, Inc, Tulsa, USA). Analysis of variance (ANOVA) was performed for each property. Statistical significant differences were analyzed a posteriori with the Tukey test. The significance level was defined as $\mathrm{p} \leq 0.05$, for all tests.

\section{Results and discussion}

\subsection{Rheological measurements}

No reliable results were achieved at 5\% WPI due to the low viscosity of the samples and the higher syneresis of the weak gel formed. In addition, films are manufactured by evaporation and concentration of the film forming solutions and the properties of a more concentrated mixture are more likely to reproduce the behavior of the film.

The final relevant rheological parameters storage moduli or elastic moduli $\left(G^{\prime}\right)$, loss or viscous moduli $\left(G^{\prime \prime}\right)$ and loss angle $(\delta)$ were measured and are shown in Fig. 1.

Storage moduli of WPI gels, obtained in the present study $\left(G^{\prime}=8077 \pm 766\right.$ Pa without glycerol; $G^{\prime}=8107 \pm 1428$ Pa with glycerol), were $\sim 40$ times higher than storage moduli of WPC gels ( $G^{\prime}=204 \pm 33$ Pa without glycerol) obtained by Rocha et al. (2009). Both studies were performed in $\mathrm{pH} 7.0$, with addition of $\mathrm{NaCl}$ to ensure constant ionic strength. This large difference between the results of these two studies can be related to the compositions of WPI and WPC. WPI used in this experiment presented protein content above $90 \%(\mathrm{w} / \mathrm{w})$, while WPC used by Rocha et al. (2009) had $82 \%(\mathrm{w} / \mathrm{w})$ protein content, on a dry weight basis. Besides their distinct protein contents, WPI and WPC differed also in the levels of other constituents such as lactose, minerals and lipids. These differences may influence markedly the intermolecular bonds in the manufactured gels, resulting in high differences in their storage moduli.

LBG and glycerol addition modified the gelation behavior of WPI. Though the overall pattern of the viscoelastic moduli with the temperature ramps followed the same behavior, the final values were significantly different. In the absence of plasticizer (glycerol), $G^{\prime}$ tends to increase with LBG concentration until $0.3 \%$. For higher LBG concentrations, the gelation ability is impaired and $\mathrm{G}^{\prime}$ decreases rapidly. In the presence of plasticizer, $G^{\prime}$ tends to increase with LBG concentration until $0.2 \%$ and presents higher value than it was observed in the gels without glycerol, for the same LBG content. For LBG concentrations higher than $0.2 \%$, the gelation ability is impaired and $\mathrm{G}^{\prime}$ decreases rapidly. For $0.3 \%$ LBG, although, it is possible observe that elastic moduli reduces in gels with plasticizer but enhance slightly in the absence of the glycerol. Loss moduli trends are similar to storage moduli trends, both with and without glycerol. Thus, it seems that the presence of glycerol shifted the maximum synergy to lower LBG concentrations (from 0.3 to $0.2 \%$ ).

Higher $G^{\prime}$ values denote an improvement of the gel strength and indicate the existence of the synergy between WPI and LBG. Rocha et al. (2009) also observed that addition of small amounts of LBG increased $\mathrm{G}^{\prime}$ of the gels containing $10 \%(\mathrm{w} / \mathrm{w})$ of whey protein concentrated (WPC) without plasticizer. In that published work, the authors verified that mixtures with $0.1 \%(\mathrm{w} / \mathrm{w})$ of $\mathrm{LBG}$ presented the highest $G^{\prime}$ value and ascribed the result to phase separation that
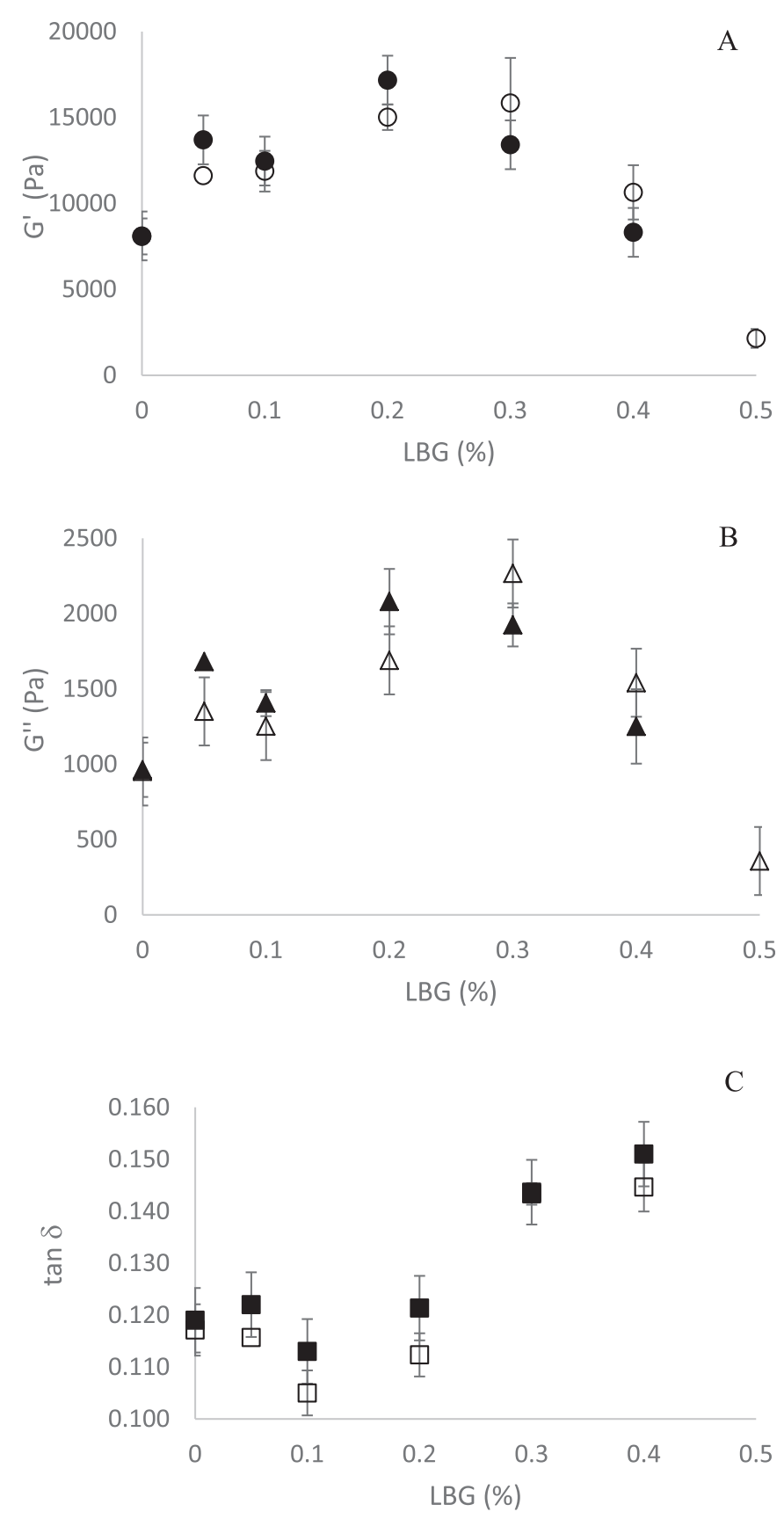

Fig. 1. Rheological parameters of whey protein isolate (WPI) aqueous gels with different concentrations of LBG and with $\left(G^{\prime}, \bullet ; G^{\prime \prime}, \boldsymbol{A} ; \delta, \boldsymbol{\square}\right)$ or without $\left(G^{\prime}, \bigcirc ; G^{\prime \prime}\right.$, $\Delta ; \delta, \square)$ glycerol.

occurs in this kind of system. The phase separation can lead to a raise in protein concentration in the continuous protein-enriched phase, increasing the elastic response of the network. For higher LBG concentrations, the phase separation overcomes the effect of the protein concentration, and gelation is impaired. WPC has higher amounts of contaminants (such as lactose) than WPI that can compete with LBG or have a similar effect. This may justify the fact that optimum LBG amount found for maximum elastic modulus $\left(G^{\prime}\right)$ was significantly higher in the present work with WPI.

The attractive forces present in WPI with $0.2 \%$ LBG could have also increased due to the glycerol addition in the gel. Chantrapornchai and McClements (2002) observed that glycerol increased the storage moduli of the $10 \%(\mathrm{w} / \mathrm{w})$ WPI gels. However, 
in this work, no significant differences were observed without LBG. Generally, plasticizers act interrupting intermolecular forces, reducing the rigidity of the gels structure and, hence, reducing storage moduli. On the other hand, lower plasticizer concentrations can produce an antiplasticization effect, interacting with the polymer and increasing $G^{\prime}$ value (Sothornvit \& Krochta, 2005). Probably LBG can be considered to behave similarly to a plasticizer in this king of gels. The antiplasticization effect is present in concentrations until $0.3 \%$ in gels without glycerol. However, when glycerol is added, the overall plasticizer concentration increases, and the maximum synergy is shifted to lower LBG concentrations.

This behavior is reflected in the value of the loss angle. However, the minimum value in this case seems to be around $0.1 \%$, though no significant differences are observed between 0 and $0.2 \%$ LBG indicating a similar viscoelastic behavior. For LBG concentrations higher than $0.2 \%$, the viscous character increases. Rocha et al. (2009) also did not find significant changes in $\tan \delta$ of WPC gels with $0.1 \%(\mathrm{w} / \mathrm{w})$ LBG.

Furthermore, the values with glycerol are consistently slightly higher than the values without glycerol, indicating the presence of glycerol slightly decreases the solid character of the gel samples.

\subsection{Mechanical properties}

Tensile strength (TS) and elongation-at-break (EB) of WPI films were analyzed for three different LBG contents and two different thermal treatments. The results are shown in Table 1.

As expected, the time of thermal treatment significantly improved the mechanical properties of WPI films, increasing both of TS and EB. In the case of EB, this effect was stronger in the presence of LBG. When the protein is heated, its structure becomes more mobile. Covalent disulphide bonds are formed among polypeptide chains, increasing the chain length and forming a stable network (Totosaus, Montejano, Salazar, \& Guerrero, 2002; Nicolai et al., 2011). Thus, an increase in the TS of ca. 50\% was achieved, leading to final TS near 3.5 MPa, in accordance with the 1-14 MPa value reported, depending on the film-making method, glycerol concentration ( $30 \%-50 \%$ of the whey protein) and environmental testing conditions (Brindle \& Krochta, 2008; McHugh \& Krochta, 1994; Ramos et al., 2013; Ustunol \& Mert, 2004). This improvement has been formerly reported. For instance, Pérez-Gago and Krochta (1999) described that aqueous solutions containing 5\% WPI heated at $90{ }^{\circ} \mathrm{C}$ for $30 \mathrm{~min}$ in $\mathrm{pH} 7.0$ with addition of glycerol (70:30, WPI:Glycerol) provides films 2.2 times stronger and approximately 6 times more resistant to deformation in comparison with films formed with non-heated WPI.

Phase incompatibility often leads to poorer mechanical properties when no specific interactions are present. However, improved mechanical properties are expected when interaction between the different components are described (Brindle \& Krochta, 2008). Though the presence of low amounts of LBG does not seem to have a significant effect on the film's tensile strength ( $p<0.05$ ), elongation at break is significantly improved for the films, providing higher capacity of the film to extend before breaking. It was verified that elongation at break of WPI film increased with the LBG concentration, being that $0.1 \%$ LBG addition in the formulation resulted in films 2.3 times more deformable. Whey protein films are formed through a combination of disulfide bonds, hydrophobic interactions and hydrogen bonds. The nature of these bonds generally leads to very brittle films (Sothornvit \& Krochta, 2001). The incorporation of a plasticizer tends to increase polymer chain mobility, thus allowing higher deformations but generally decreasing films' tensile strength. It will position between the biopolymer chains within the polymer network, increasing the mobility by increasing the intermolecular spacing (Wihodo \& Moraru, 2013). LBG seems to have a similar plasticizing effect, since elongation capacity was enhanced. Nevertheless, tensile strength was not impaired with LBG addition. A probable phase separation between WPI and LBG will lead to an enriched phase in protein and an enriched phase in LBG. For LBG concentrations low enough, this phase separation will still allow to form a continuous protein network by the protein enriched-phase. As the protein concentration increased in this phase (it was excluded from the other phase), this network is stronger than the original, without LBG. Similar behavior was observed by Rocha et al. (2009) in gels constituted of WPC + LBG. On the other hand, an enriched phase in LBG would be responsible by the plasticizing effect. Hence, an expected decrease in the tensile strength due to this plasticizer effect may have been compensated for the strengthening of the protein network detected by rheology results.

\subsection{Solubility and water sorption isotherms}

The values obtained of solubility for whey protein isolate films with and without addition of LBG are presented in Table 1.

Solubility of WPI films decreased with time of thermal treatment indicating that the greater the cross-linking effect in the matrix the less soluble is the film (Table 1). According to Pelegrine and Gasparetto (2005), protein-protein irreversible binding reduce water interaction in solutions reducing the solubility of the films. Heat denaturation enables the formation of intermolecular irreversible disulfide bonds, which are among the strongest intermolecular bonds. For shorter times, this exposure may not be complete and hydrogen bonding and hydrophobic intermolecular interactions may still have a strong contribution to the film formation, leading to more soluble films (Floris, Bodnar, Weinbreck, \& Alting, 2008). This behavior is also in accordance with the results found by Pérez-Gago and Krochta (2001).

LBG addition also decreased solubility in thermally treated films for $10 \mathrm{~min}$. However in films with thermal treatment until $75^{\circ} \mathrm{C}$ the solubility increased with polysaccharide addition. This result also confirm that time of heating was not enough to establish enough

Table 1

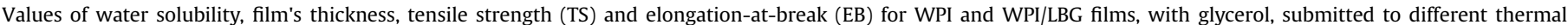
treatment.

\begin{tabular}{|c|c|c|c|c|c|c|c|c|}
\hline \multirow[t]{2}{*}{ Treatment } & \multicolumn{4}{|c|}{ Thermal treatment (until $75^{\circ} \mathrm{C}$ ) } & \multicolumn{4}{|c|}{ Thermal treatment $\left(75^{\circ} \mathrm{C} / 10 \mathrm{~min}\right)$} \\
\hline & Solubility (\%) & Thickness (mm) & TS (MPa) & EB (\%) & Solubility (\%) & Thickness (mm) & TS (MPa) & EB $(\%)$ \\
\hline $5 \%$ WPI & $62.04 \pm 0.74^{\mathrm{a}, \mathrm{A}}$ & $0.26 \pm 0.062^{\mathrm{a}, \mathrm{A}}$ & $2.34 \pm 0.33^{\mathrm{a}, \mathrm{A}}$ & $11.04 \pm 1.63^{\mathrm{a}, \mathrm{A}}$ & $59.97 \pm 0.19^{\mathrm{a}, \mathrm{B}}$ & $0.29 \pm 0.025^{\mathrm{a}, \mathrm{A}}$ & $3.53 \pm 0.27^{\mathrm{a}, \mathrm{B}}$ & $13.89 \pm 4.41^{\mathrm{a}, \mathrm{A}}$ \\
\hline $5 \%$ WPI $+0.025 \%$ LBG & $73.51 \pm 1.64^{\mathrm{b}, \mathrm{A}}$ & $0.28 \pm 0.013^{\mathrm{a}, \mathrm{A}}$ & $2.66 \pm 0.46^{\mathrm{a}, \mathrm{A}}$ & $10.92 \pm 2.33^{\mathrm{a}, \mathrm{A}}$ & $54.52 \pm 0.39^{\mathrm{b}, \mathrm{B}}$ & $0.28 \pm 0.017^{\mathrm{a}, \mathrm{A}}$ & $3.26 \pm 0.23^{\mathrm{a}, \mathrm{B}}$ & $18.56 \pm 3.61^{\mathrm{ab}, \mathrm{B}}$ \\
\hline $5 \%$ WPI $+0.05 \%$ LBG & $69.70 \pm 0.38^{\mathrm{c}, \mathrm{A}}$ & $0.29 \pm 0.019^{\mathrm{a}, \mathrm{A}}$ & $2.35 \pm 0.28^{\mathrm{a}, \mathrm{A}}$ & $9.68 \pm 2.41^{\mathrm{a}, \mathrm{A}}$ & $55.16 \pm 1.92^{\mathrm{b}, \mathrm{B}}$ & $0.29 \pm 0.019^{\mathrm{a}, \mathrm{A}}$ & $3.65 \pm 0.39^{\mathrm{a}, \mathrm{B}}$ & $23.16 \pm 5.68^{\mathrm{b}, \mathrm{B}}$ \\
\hline $5 \% \mathrm{WPI}+0.1 \% \mathrm{LBG}$ & $62.37 \pm 0.89^{\mathrm{a}, \mathrm{A}}$ & $0.29 \pm 0.06^{\mathrm{a}, \mathrm{A}}$ & $2.78 \pm 0.29^{\mathrm{a}, \mathrm{A}}$ & $19.25 \pm 8.23^{\mathrm{b}, \mathrm{A}}$ & $56.74 \pm 0.39^{\mathrm{b}, \mathrm{B}}$ & $0.28 \pm 0.03^{\mathrm{a}, \mathrm{A}}$ & $3.63 \pm 0.33^{\mathrm{a}, \mathrm{B}}$ & $32.09 \pm 6.74^{\mathrm{c}, \mathrm{B}}$ \\
\hline
\end{tabular}

Mean \pm SD

Means with the same capital letter, for the same response variable, in the same line did not differ significantly at $\mathrm{p} \leq 0.05$, according to the Tukey test.

Means with the same lower case letter, in the same column, did not differ significantly at $\mathrm{p} \leq 0.05$, according to the Tukey test. 
disulfide bonds and that hydrophobic interactions and hydrogen bonding still play the dominant role. LBG is water soluble and, unless other phenomena are involved, it is likely to increase film water solubility.

The decrease in solubility observed with addition of LBG to thermally treated films is probably related to the increase in the thermal cross-linking effect. Rocha et al. (2009) analyzed the microstructure of whey protein concentrate (WPC) + LBG gels and observed phase-separation with LBG promoting protein aggregation. The protein concentration in the protein-enriched phase was probably higher, leading to a stronger network with more disulfide bonds. A similar mechanism seems to occur also in WPI films with the LBG addition resulting in reduced film solubility. Though these films are still partially soluble, their solubility can be further decreased by chemical modification of the residual accessible thiol groups (by blocking or copper-catalyzed oxidation (Floris et al., 2008)).

The sorption isotherms of WPI films with or without LBG, obtained experimentally, are presented in Fig. 2.

The treatment time and the addition of LBG to WPI films barely changed the amount of moisture adsorbed per mass of dry solids. All curves showed that the films undergo considerable changes with the relative humidity of the environment adsorbing large amounts of water at high relative humidity and small amounts at low relative humidity (Fig. 2).

The results of nonlinear regression analysis of experimental data with the GAB model presented in Table 2 showed high correlation coefficients $\left(R^{2} \geq 0.99\right)$ suggesting that the model adequately fits the experimental data.

\subsection{Oxygen, carbon dioxide and water vapor permeabilities}

Oxygen permeability $\left(\mathrm{O}_{2} \mathrm{P}\right)$, carbon dioxide permeability $\left(\mathrm{CO}_{2} \mathrm{P}\right)$ and water vapor permeability (WVP) of WPI films with or without LBG are shown in Table 3.

Though, for all samples, WVP's were always higher for the stronger heat treatment, the WVP values shown in Table 3 indicate that thermal treatments affected significantly WVP of films only with 0.05 and $0.1 \%$ LBG. These results are also consistent with Pérez-Gago, Nadaud, and Krochta (1999) that also verified that thermal treatment had no significant effect on WVP of 5 and $10 \%$ WPI films made at $\mathrm{pH}$ 7.0. Furthermore, for the strongest heat treatment, when the disulfide bonds are fully established, WVP seems to be consistently higher for films with LBG. For milder heat treatments, the hydrophilic nature of WPI and LBG is more similar, which can justify the absence of differences in the WVP. For instance, Jiménez, Fabra, Talens, and Chiralt (2012) also verified that the inclusion of hydroxyproprylmethylcellulose in starch-based

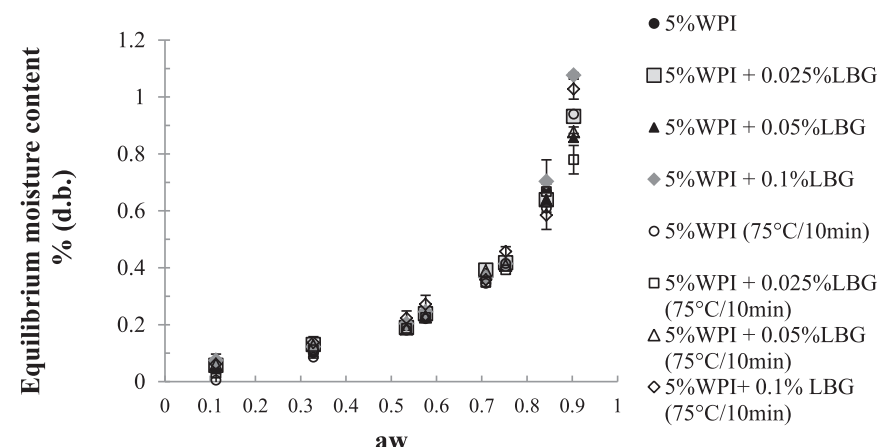

Fig. 2. Experimental values of equilibrium moisture content (dry basis), as a function of water activity for different films formulations.
Table 2

Parameters of GAB model fit to experimental data of sorption isotherms of WPI films, with glycerol and with or without thermal treatment time and LBG addition.

\begin{tabular}{lrllll}
\hline & $\mathrm{C}$ & $\mathrm{K}$ & $\mathrm{X}_{\mathrm{m}}$ & $\mathrm{R}^{2}$ & RQMR \\
\hline 5\% WPI & 2.43 & 0.954 & 0.139 & 0.998 & $1.38 \%$ \\
$5 \%$ WPI $+0.025 \% \mathrm{LBG}$ & 4.19 & 0.959 & 0.129 & 0.997 & $1.46 \%$ \\
$5 \%$ WPI $+0.05 \% \mathrm{LBG}$ & 2.14 & 0.922 & 0.158 & 0.998 & $1.28 \%$ \\
$5 \%$ WPI $+0.1 \% \mathrm{LBG}$ & 7.01 & 0.992 & 0.115 & 0.998 & $1.27 \%$ \\
$5 \%$ WPI $\left(75{ }^{\circ} \mathrm{C} / 10 \mathrm{~min}\right)$ & 1.75 & 0.957 & 0.139 & 0.998 & $1.22 \%$ \\
$5 \%$ WPI $+0.025 \% \mathrm{LBG}\left(75^{\circ} \mathrm{C} / 10 \mathrm{~min}\right)$ & 0.63 & 0.816 & 0.329 & 0.989 & $2.64 \%$ \\
$5 \%$ WPI $+0.05 \% \mathrm{LBG}\left(75^{\circ} \mathrm{C} / 10 \mathrm{~min}\right)$ & 3.13 & 0.942 & 0.139 & 0.991 & $1.78 \%$ \\
$5 \%$ WPI $+0.1 \% \mathrm{LBG}\left(75^{\circ} \mathrm{C} / 10 \mathrm{~min}\right)$ & 12.19 & 0.987 & 0.111 & 0.989 & $1.78 \%$ \\
\hline
\end{tabular}

films led to films with similar WVP due to the similar hydrophilic character. For the stronger heat treatment, the interactions between the protein molecules in the film network are stronger. Furthermore, these protein intermolecular interactions are of hydrophobic nature or through disulfide bonds. This will probably leave the hydrophilic LBG molecules more available to interact with the water vapor molecules.

A significant reduction in oxygen and carbon dioxide permeability was observed with the thermal treatment. The lowest values were observed in films heated for $10 \mathrm{~min}$. These results are consistent with the results found by other authors for different heat treatments or degrees of cross-linking of whey proteins. In fact, Pérez-Gago and Krochta (2001) also found a tendency for decrease of $\mathrm{O}_{2} \mathrm{P}$ with the heat treatment. Ustunol and Mert (2004) and Yoo and Krochta (2011) found an increase in the WVP and decrease in $\mathrm{O}_{2} \mathrm{P}$ when a crosslinking agent was added to the WPI.

The reduction of oxygen and carbon dioxide permeability with LBG addition observed in Table 3, confirms that LBG improved the intermolecular attractions between polymeric chains, increasing structural cohesion of WPI films and hampering the penetration of gas molecules. This reduction has been observed in both thermal treatments indicating that the synergy occurred for different degrees of cross-linking of WPI. The lowest oxygen permeability values were observed in films with $0.1 \%$ LBG.

The presence of the polysaccharide seems to decrease the overall film hydrophobicity, allowing higher affinity towards water and, thus, higher water vapor permeabilities. In contrast, carbon dioxide and oxygen permeabilities decrease reinforcing this less apolar character. Oxygen is a non-polar molecule with a very low affinity towards water. It is expected to absorb to a greater extent in less polar polymers and have an inverse behavior when compared to water. $\mathrm{CO}_{2}$ has usually a behavior similar to $\mathrm{O}_{2}$, though slightly less marked $\left(\mathrm{O}_{2}\right.$ is more apolar). Thus, for highly hydrophilic films such as polysaccharide- or protein-based films, WVP is usually quite high while $\mathrm{O}_{2} \mathrm{P}$ and $\mathrm{CO}_{2} \mathrm{P}$ are usually remarkably low (e.g. Wihodo \& Moraru, 2013) being the former lower than the last. Nevertheless, even though the composition and the nature of each components are important, the interactions between the different components of the film matrices exercise also strong influence on the resulting WVP and $\mathrm{O}_{2} \mathrm{P}$ (Acosta, Jiménez, Cháfer, GonzálezMartínez, \& Chiralt, 2015). Therefore, the addition of a more hydrophilic compound does not always result in a strong increase of the WVP. For instance, Acosta et al. (2015) did not find significant differences with the addition of gelatin to starch, even though gelatin alone is highly hydrophilic.

This higher oxygen and carbon dioxide barrier promoted by LBG addition can help in improving food quality and extending food shelf life, e.g. reducing oxidative browning in minimally processed products or protecting foods against oxygen during storage in environment with low relative humidity. Silva, Garcia, Amado, and Mauro (2015) verified that coating from 5\% WPI + 0.05\% LBG $+2 \%$ glycerol was an effective barrier to oxygen because it reduced the 


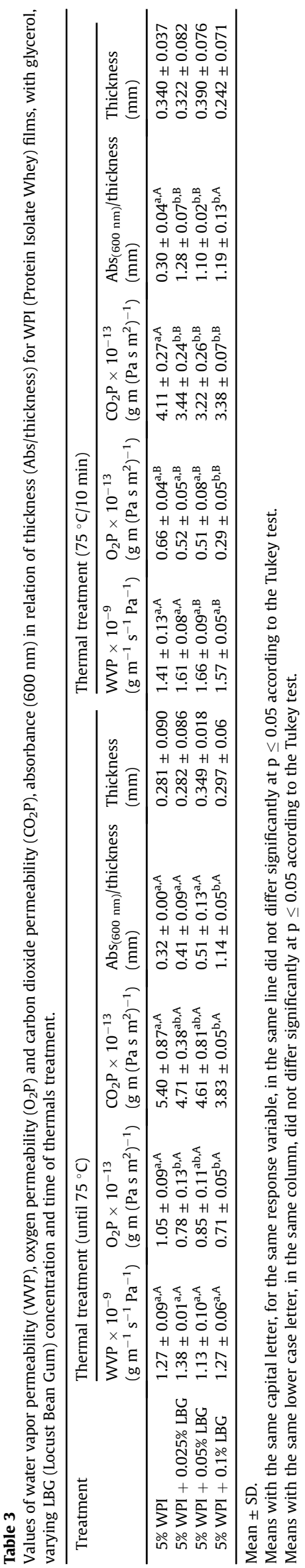

losses of ascorbic acid of pineapple slices during drying at $60^{\circ} \mathrm{C}$ in comparison with non-coated samples.

\subsection{Optical properties}

Transmittance and absorbance of WPI films with and without LBG at different wavelengths are presented in Figs. 3 and 4, respectively.

Transmittance of WPI films with a stronger heat treatment clearly decreased in the visible range region (350-800 nm) with LBG addition, thereby reducing the transparency of the films (Fig. 3). However, films with a milder heat treatment only showed their transparency affected with the addition of at least 0.05\% LBG (Fig. 3). Furthermore, for the absorbance normalized by the film thickness, this difference was only visible for the film with $0.1 \%$ LBG (Table 3). Transparency depends on the microstructure of the films (Acosta et al., 2015) and the results are in accordance with the SEM analyses discussed below, which show an increase in the heterogeneity of the films' structure with the increase of the LBG concentration. Furthermore, these differences are also more evident in the SEM pictures for the strongest heat treatment. Phase separation due to thermodynamic incompatibility between polysaccharide and protein can slightly enhance the turbidity of the system due to differences in the light dispersion within the different phases. This can diminish the transparency of WPI films. According to Jiménez et al. (2012), optical properties are influenced by the structural arrangement of the biopolymer molecules. Phase separation can lead to discontinuities in the refractive index thus affecting transparency. Yoo and Krochta (2011) also observed reduction in transparency of WPI films with the addition of polysaccharides that show incompatibility with whey proteins. WPI-based films are
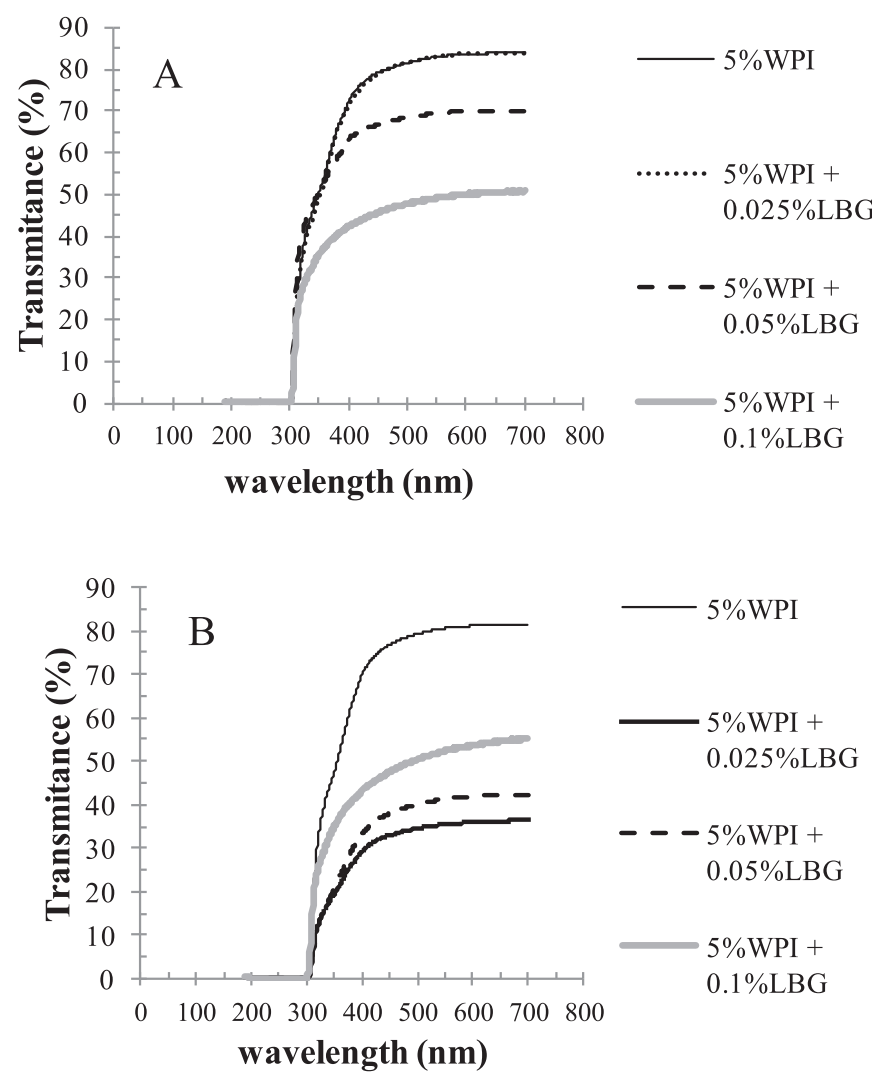

Fig. 3. Transmittance of WPI films without (A) and with (B) thermal treatment time sweep and LBG addition at different wavelengths. 


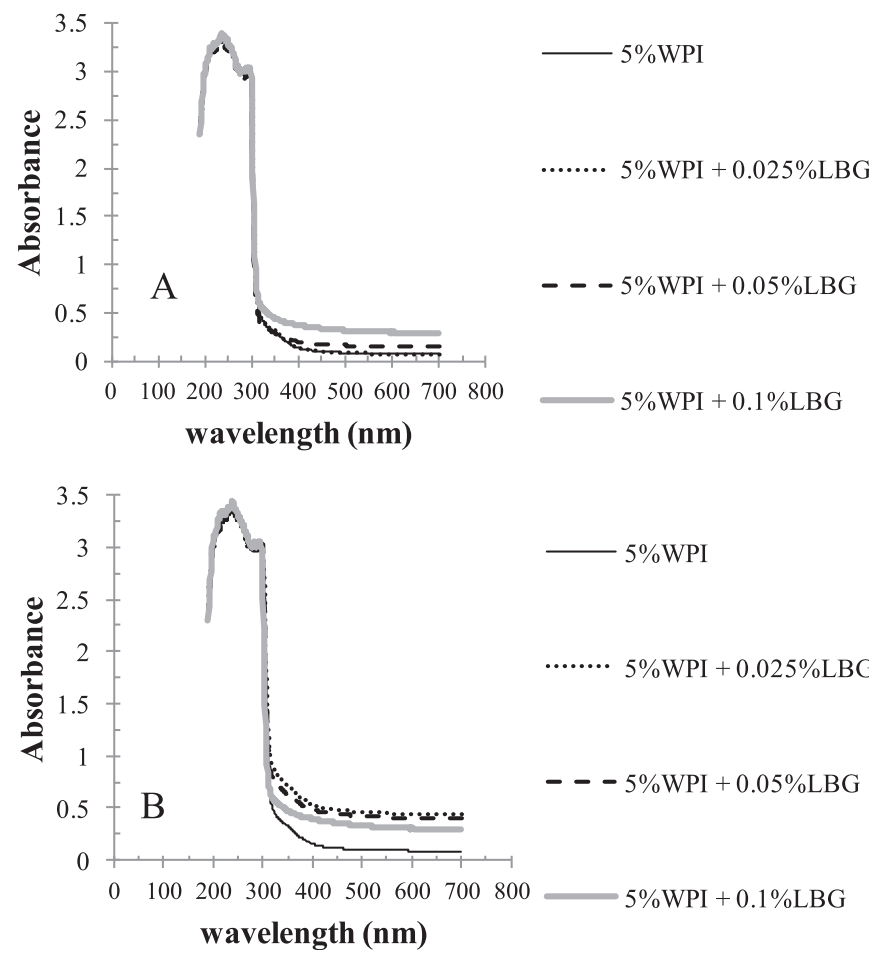

Fig. 4. Absorbance of WPI films without (A) and with (B) thermal treatment time sweep and LBG addition at different wavelengths.

usually transparent and colorless (e.g. Brindle \& Krochta, 2008). In two phase systems with a continuous matrix and dispersed domains with different viscosities, light refracts from these domains causing a translucent appearance (Brindle \& Krochta, 2008) and decreasing transparency.

Depending on the application, a higher transparency may be desirable from the consumer's point of view, but an increased barrier may be beneficial for the preservation of the food. WPI films presented a higher barrier property to light, in the visible range, with time of thermal treatment and with LBG addition, as shown in absorbance spectra (Fig. 4). Differences between films' thickness did not influence this result, as observed in Table 3, being that the increased structural cohesion of films due to a higher cross-linking effect with thermal treatment and LBG addition was the determinant factor to increase barrier properties of WPI films.

In the UV range, WPI films generally hold excellent barrier properties due to the high content of aromatic amino-acids, being able to impair UV light induced lipid oxidation (Ramos et al., 2013). This property was not affected by the presence of a small amount of LBG (Fig. 4). The increase in barrier properties to light and the reduction in oxygen permeability make WPI-based films with LBG a good alternative to protect food against oxidative reactions.

\subsection{Integrated evaluation of WPI/LBG film properties based on the microstructure analysis}

Fig. 5 shows the structure of WPI films with $4 \%$ glycerol $(w / w)$, different LBG concentrations and two different thermal treatments. Differences were not clearly visible between the two heat treatments.

The heterogeneity of the films' structure increases with the increase of the LBG concentration. A "ridge and valley" structure seems to be present in films with 0.05\% LBG (Fig. 5c) and in films with $0.1 \%$ LBG (Fig. 5d), as described for other plasticized protein films. This "ridges and valleys" structure has been described to be related to more ductile materials (Wihodo \& Moraru, 2013). Smoother microstructures are usually related to more glassy and brittle materials.

In Fig. $5 c$ and $d$, it is possible to observe that the biphasic character is reinforced in the presence of a small amount of LBG. This is consistent with the fact that the majority of polysaccharide/ protein mixed systems present thermodynamic incompatibility with segregative phase separation, being that each phase is enriched in one of the biopolymers (e.g. Grinberg \& Tolstoguzov, 1997). A thicker continuous protein network seems to be formed and the intervals probably correspond to LBG/glycerol enricheddomains, acting as fillers. Protein is apparently more aggregated and pores (LBG-enriched domains) are larger than for films without LBG. For whey protein gels, this segregative phase-separation has been described to locally increase the protein concentration. For
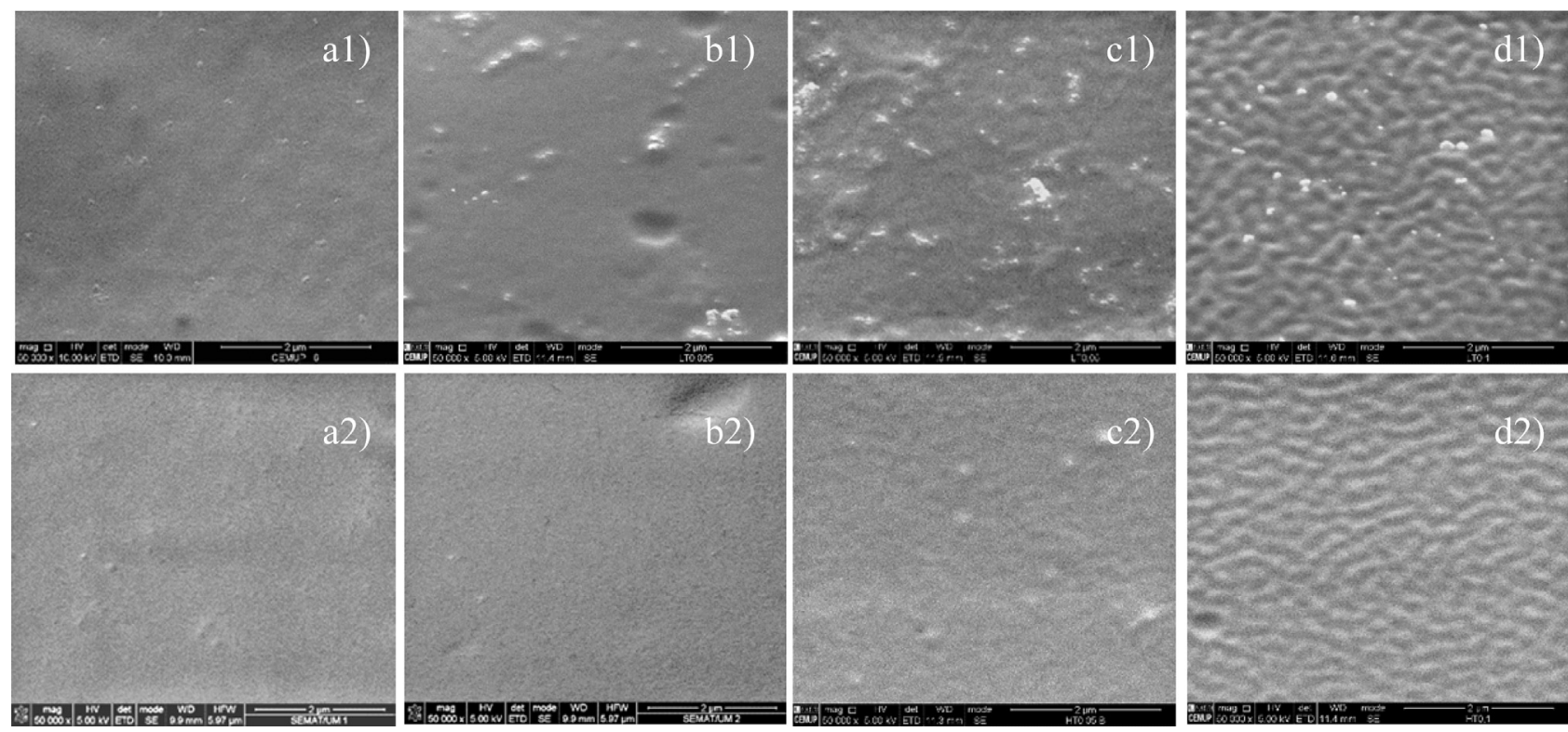

Fig. 5. Structure of the WPI (5\%)/LBG films (surface) with $2 \%$ glycerol $(w / w): a) 0 \%$ LBG; b) $0.025 \%$ LBG; c) $0.05 \%$ LBG; d) $0.1 \%$ LBG; $1:$ until $75{ }^{\circ} \mathrm{C} ; 2: 75{ }^{\circ} \mathrm{C} / 10$ min. 
very low amounts of LBG (ca. $0.1 \%$ ), the LBG enriched domains act as fillers to reinforce the gel structure without affecting the connectivity, leading to an increase in the elastic response (Rocha et al., 2009). Apparently, the same happens in the LBG/WPI films. This reinforces what has been written above for the mechanical properties.

These larger pores may be responsible for the WVP increase, as it is likely that water vapor moves along the films through these highly hydrophilic domains. On the contrary, $\mathrm{O}_{2}$ and $\mathrm{CO}_{2}$ affinity for these domains is reduced and it should be easier for them to move along the protein network (Anker, Stading, \& Hermansson, 2000). Therefore, as the protein network is reinforced in the presence of LBG, $\mathrm{O}_{2}$ and $\mathrm{CO}_{2}$ permeabilities are reduced, as it is more difficult to pass through a more compact structure.

As already mentioned, whey protein films are usually very brittle and need a significant amount of a plasticizer to reduce their brittleness. In order to reduce this need, partial hydrolysis of whey proteins has been suggested (Sothornvit \& Krochta, 2000). The addition of a very small amount of LBG seems to be as effective and much easier to perform.

\section{Conclusions}

The inclusion of LBG resulted in more flexible WPI-based films, with higher permeability to water and with improved $\mathrm{O}_{2}, \mathrm{CO}_{2}$ and light barrier properties making them a good alternative to protect food against oxidative reaction. The severity of the thermal treatment was important to form a stable network with higher crosslinking effect in the matrix, higher molecular interactions and, consequently, stronger and less soluble films with improved barrier properties to carbon dioxide, oxygen and light. Films made from solutions with $5 \% \mathrm{WPI}+0.1 \% \mathrm{LBG}+2 \%$ glycerol, heated at $75{ }^{\circ} \mathrm{C}$ for 10 min presented the lower oxygen permeability (more than $50 \%$ decrease when compared with the film with no LBG, with the same thermal treatment). Thus the addition of LBG to WPI films can be useful e.g. to reduce oxidative browning in minimally processed products or to protect foods against oxygen during storage in environment with low relative humidity. Moreover, this combination can be used as effective vector to carry and deliver nutraceutical compounds sensitive to oxygen.

Interaction between WPI and LBG strongly influence film properties and it is thus possible to tune the properties of edible films from WPI adding different amounts of LBG and/or using different thermal treatments.

\section{Acknowledgment}

This work was supported by Fundação para a Ciência e a Tecnologia through contract UID/QUI/50006/2013. The work also received financial support from the European Union (FEDER funds) under the framework of QREN (Programa Operacional Regional do Norte ON.2 - O Novo Norte) through project NORTE-07-0124FEDER-000069. K. Silva was funded by CAPES (grant 5292/11-5).

\section{References}

Acosta, S., Jiménez, A., Cháfer, M. González-Martínez, C. \& Chiralt, A. (2015). Physical properties and stability of starch-gelatin based films as affected by the addition of esters of fatty acids. Food Hydrocolloids, 49, 135-143.

Anker, M., Stading, M., \& Hermansson, A.-M. (2000). Relationship between the microstructure and the mechanical and barrier properties of whey protein films. Journal of Agricultural and Food Chemistry, 48, 3806-3816.

Arvanitoyannis, I., \& Biliaderis, C. G. (1998). Physical properties of polyol-plasticized edible films made from sodium caseinate and soluble starch blends. Food Chemistry, 62(3), 333-342.

Arvanitoyannis, I., Psomiadou, E., \& Nakayama, A. (1996). Edible films made from sodium caseinate, starches, sugars or glycerol. Part 1. Carbohydrate Polymers, 31
179-192.

Arvanitoyannis, I., Psomiadou, E., Nakayama, A., Aiba, S., \& Yamamoto, N. (1997) Edible films made from gelatin, soluble starch and polyols, Part 3. Food Chemistry, 60, 593-604.

ASTM D3985-02. (2002). Standard test method for oxygen gas transmission rate through plastic film and sheeting using a coulometric sensor. In Annual book of ASTM. Amer. Soc. for Testing \& Materials, Philadelphia, PA.

ASTM D882-91. (1991). Standard test methods for tensile properties of thin plastic. In Annual Book of ASTM Standards. Amer. Soc. for Testing \& Materials, Philadelphia, PA.

ASTM E96-95. (1995). Standard test methods for water vapor transmission of materials. In Annual Book of ASTM standards. Washington, DC: American Society for Testing and Materials.

Baeza, R., Sanchez, C. C., Pilosof, A. M. R., \& Patino, J. M. R. (2005). Interactions of polysaccharides with $\beta$-lactoglobulin adsorbed films at the air-water interface. Food Hydrocolloids, 19, 239-248.

Barak, S., \& Mudgil, D. (2014). Locust bean gum: processing, properties and food applications-A review. International Journal of Biological Macromolecules, 66, 74-80.

Beaulieu, M., Turgeon, S. L., \& Doublier, J. L. (2001). Rheology, texture and microstructure of whey proteins/low methoxyl pectins mixed gels with added calcium. International Dairy Journal, 11(11-12), 961-967.

Bozdemir, O. A., \& Tutas, M. (2003). Plasticiser effect on water vapour permeability properties of locust bean gum-based edible films. Turkish Journal of Chemistry, 27, 773-782.

Brindle, L. P., \& Krochta, J. M. (2008). Physical properties of whey proteinhydroxypropylmethylcellulose blend edible films. Journal of Food Science, 73(9), 446-454.

Cerqueira, M. A., Bourbon, A. I., Pinheiro, A. C., Martins, J. T., Souza, B. W. S., Teixeira, J. A., et al. (2011). Galactomannans use in the development of edible films/coatings for food applications. Trends in Food Science \& Technology, 22, $662-671$.

Cerqueira, M. A., Souza, B. W. S., Teixeira, J. A., \& Vicente, A. A. (2012). Effect of glycerol and corn oil on physicochemical properties of polysaccharide films - a comparative study. Food Hydrocolloids, 27, 175-184.

Chantrapornchai, W., \& McClements, D. J. (2002). Influence of glycerol on optical properties and large-strain rheology of heat-induced whey protein isolate gels. Food Hydrocolloids, 16, 461-466.

Coughlan, K., Shaw, N. B., Kerry, J. F., \& Kerry, J. P. (2004). Combined effects of proteins and polysaccharides on physical properties of whey protein concentrate-based edible films. Journal of Food Science, 69(6), E271-E275.

Cuq, B., Gontard, N., Cuq, J.-L., \& Guilbert, S. (1996). Functional properties of myofibrillar protein-based biopackaging as affected by film thickness. Journal of Food Science, 61(3), 580-584.

Dakia, P. A., Blecker, C., Robert, C., Wathelet, B., \& Paquot, M. (2008). Composition and physicochemical properties of locust bean gum extracted from whole seeds by acid or water dehulling pre-treatment. Food Hydrocolloids, 22, 807-818.

Daniel, C., \& Wood, F. (1980). Fitting equations to data (Revised Edition). New York, USA: John Wiley \& Sons.

Fernandes, P. B., Gonçalves, M. P., \& Doublier, J. L. (1991). A rheological characterization of kappa-carrageenan/galactomannan mixed gels: a comparison of locust bean gum samples. Carbohydrate Polymers, 16, 253-274.

Floris, R., Bodnar, I., Weinbreck, F., \& Alting, A. C. (2008). Dynamic rearrangement of disulfide bridges influences solubility of whey protein coatings. International Dairy Journal, 18(5), 566-573.

Gonçalves, M. P., Sittikijyothin, W., Silva, M. V., \& Lefebvre, J. (2004). A study of the effect of locust bean gum on the rheological behaviour and microstructure of a b-lactoglobulin gel at pH 7. Rheologica Acta, 43, 472-481.

Gounga, M. E., Xu, S. Y., \& Wang, Z. (2007). Whey protein isolate-based edible films as affected by protein concentration, glycerol ratio and pullulan addition in film formation. Journal of Food Engineering, 83, 521-530.

Goycoolea, F. M., Morris, E. R., \& Gidley, M. J. (1995). Viscosity of galactomannans at alkaline and neutral pH: evidence of 'hyperentanglement' in solution. Carbohydrate Polymers, 27, 69-71.

Grinberg, V. Ya, \& Tolstoguzov, V. B. (1997). Thermodynamic incompatibility of proteins and polysaccharides in solutions. Food Hydrocolloids, 11, 145-158.

Han, J. H., \& Gennadios, A. (2005). Edible films and coatings: a review. Innovations in Food Packaging, 239-262.

Hong, S.-I., \& Krochta, J. M. (2006). Oxygen barrier performance of wheyproteincoated plastic films as affected by temperature, relative humidity, base film and protein type. Journal of Food Engineering, 77, 739-745.

Ibanoglu, E. (2002). Rheological behaviour of whey protein stabilized emulsions in the presence of gum Arabic. Journal of Food Engineering, 52, 273-277.

Ibanoglu, E. (2005). Effect of hydrocolloids on the thermal denaturation of proteins. Food Chemistry, 90, 621-626.

Jiménez, A. Fabra, M. J. Talens, P. \& Chiralt, A. (2012). Influence of hydroxypropylmethylcellulose addition and homogenization conditions on properties and ageing of corn starch based films. Carbohydrate Polymers, 89(2), 676-686.

Jowitt, R., Escher, F., Hallstom, B. Meffert, H. F. T., Spiess, W. E. L., \& Vos, G. (1987) Physical properties of foods. London and New York: Applied Science Publishers.

Kokoszka, S., Debeaufort, F., Lenart, A., \& Voilley, A. (2010). Water vapour permeability, thermal and wetting properties of whey protein isolate based edible films. International Dairy Journal, 20, 53-60.

Lee, J. Y., Park, H. J., Lee, C. Y., \& Choi, W. Y. (2003). Extending shelf-life of minimally processed apples with edible coatings and antibrowning agents. Lebensm Wiss 
U Technol, 36, 323-329.

Maier, H., Anderson, M., Karl, C., Magnuson, K., \& Whistler, R. L. (1993). Guar, locust bean, tara and fenugreek gums. In R. L. Whistler, \& J. N. BeMiller (Eds.), Industrial gums, polysaccharides and their derivates (pp. 205-215). San Diego: Academic Press.

McHugh, T. H., Avena-Bustillos, R. J., \& Krochta, J. M. (1993). Hydrophilic edible film: modified procedure for water vapor permeability and explanation of thickness effects. Journal of Food Science, 58, 899-903.

McHugh, T. H., \& Krochta, J. M. (1994). Sorbitol- vs glycerol-plasticized whey protein edible films: Integrated oxygen permeability and tensile property evaluation. Journal of Agricultural and Food Chemistry, 42(4), 841-845.

Neirynck, N., Van der Meeren, P., Lukaszewicz-Lausecker, M., Cocquyt, J., Verbeken, D., \& Dewettinck, K. (2007). Influence of $\mathrm{pH}$ and biopolymer ratio on whey protein-pectin interactions in aqueous solutions and in $\mathrm{O} / \mathrm{W}$ emulsions. Colloids and Surfaces A: Physicochemical and Engineering Aspects, 298, 99-107.

Nicolai, T., Britten, M., \& Schmitt, C. (2011). B-Lactoglobulin and WPI aggregates: formation, structure and applications. Food Hydrocolloids, 25, 1945-1962.

Osés, J., Fabregat-Vázquez, M., Pedroza-Islas, R., Tomás, S. A., Cruz-Orea, A., \& Maté, J. I. (2009). Development and characterization of composite edible film based on whey protein isolate and mesquite gum. Journal of Food Engineering, 92, 56-62.

Ozdemir, M., \& Floros, J. D. (2008). Optimization of edible whey proteins. Films containing preservatives for water vapour permeability, water solubility and sensory characteristics. Journal of Food Engineering, 86, 215-224.

Pelegrine, D. H. G., \& Gasparetto, C. A. (2005). Whey proteins solubility as function of temperature and pH. Lebensmittel Wissenschaft \& Technologie, 38, 77-80.

Pereira, R. N., Souza, B. W., Cerqueira, M. A., Teixeira, J. A., \& Vicente, A. A. (2010). Effects of electric fields on protein unfolding and aggregation: influence on edible films formation. Biomacromolecules, 11, 2912-2918.

Pérez-Gago, M. B., \& Krochta, J. M. (1999). Water vapor permeability of whey protein emulsion films as affected by pH. Journal of Food Science, 64(4), 695-698.

Pérez-Gago, M. B., \& Krochta, J. M. (2001). Denaturation time and temperature effects on solubility, tensile properties, and oxygen permeability of whey protein edible films. Journal of Food Science, 66(5), 705-710.

Pérez-Gago, M. B., \& Krochta, J. M. (2002). Formation and properties of whey protein films and coatings. In A. Gennadios (Ed.), Protein-based films and coatings (pp. 159-180). Boca Raton FL, USA: CRC Press.

Pérez-Gago, M. B., Nadaud, P., \& Krochta, J. M. (1999). Water vapor permeability, solubility, and tensile properties of heat-denatured versus native whey protein films. Journal of Food Science, 64(6), 1034-1037.

Pierro, P., Sorrentino, A., Mariniello, L., Valeria, L. C., \& Porta, R. (2011). Chitosan/ whey protein film as active coating to extend Ricotta cheese shelf-life. LWT Food Science and Technology, 44, 2324-2327.

Pollard, M. A., \& Fischer, P. (2006). Partial aqueous solubility of low-galactosecontent galactomannans-What is the quantitative basis? Current Opinion in
Colloid \& Interface Science, 11, 184-190.

Ramos, O. L., Fernandes, J. C., Silva, S. I., Pintado, M. E., \& Malcata, F. X. (2012). Edible films and coatings from whey proteins: a review on formulation, and on mechanical and bioactive properties. Critical Reviews in Food Science and Nutrition, 52, 533-552.

Ramos, O. L., Reinas, I., Silva, S. I., Fernandes, J. C., Cerqueira, M. A., Pereira, R. N. et al. (2013). Effect of whey protein purity and glycerol content upon physical properties of edible films manufactured therefrom. Food Hydrocolloids, 30(1) $110-122$.

Rocha, C., Teixeira, J. A., Hilliou, L., Sampaio, P., \& Gonçalves, M. P. (2009). Rheological and structural characterization of gels from whey protein hydrolysates/ locust bean gum mixed systems. Food Hydrocolloids, 23, 1734-1745.

Seydim, A. C., \& Sarikus, G. (2006). Antimicrobial activity of whey protein based edible films incorporated with oregano, rosemary and garlic essential oils. Food Research International, 39, 639-644.

Silva, K. S., Garcia, C. C., Amado, L. R., \& Mauro, M. A. (2015). Effects of edible coatings on convective drying and characteristics of the dried pineapple. Food and Bioprocess Technology, 8, 1465-1475.

Sittikijyothin, W., Torres, D., \& Gonçalves, M. P. (2005). Modelling the rheological behaviour of galactomannan aqueous solutions. Carbohydrate Polymers, 59, $339-350$.

Sothornvit, R., \& Krochta, J. M. (2000). Water vapor permeability and solubility of films from hydrolyzed whey protein. Journal of Food Science, 65(4), 700-703.

Sothornvit, R., \& Krochta, J. M. (2001). Plasticizer effect on mechanical properties of beta-lactoglobulin films. Journal of Food Engineering, 50(3), 149-155.

Sothornvit, R., \& Krochta, J. M. (2005). Plasticizers in edible films and coatings. Innovations in Food Packaging, 403-433.

Sun, C., Gunasekaran, S., \& Richards, M. P. (2007). Effect of xanthan gum on physicochemical properties of whey protein isolate stabilized oil-in-water emulsions. Food Hydrocolloids, 21, 555-564.

Totosaus, A., Montejano, J. G., Salazar, J. A., \& Guerrero, I. (2002). A review of physical and chemical protein-gel induction. International Journal of Food Science \& Technology, 37(6), 589-601.

Ustunol, Z., \& Mert, B. (2004). Water solubility, mechanical, barrier, and thermal properties of cross-linked whey protein isolate-based films. Journal of Food Science, 69(3), 129-133.

Van den Berg, C., \& Bruin, S. (1981). Water activity and its estimation in food systems. In L. B. Rockland, \& G. F. Stewart (Eds.), Water activity: Influences on food quality (pp. 147-177). New York: Academic Press.

Wihodo, M., \& Moraru, C. I. (2013). Physical and chemical methods used to enhance the structure and mechanical properties of protein films: a review. Journal of Food Engineering, 114(3), 292-302.

Yoo, S. R., \& Krochta, J. M. (2011). Whey protein-polysaccharide blended edible film formation and barrier, tensile, thermal and transparency properties. Journal Science Food Agriculture, 91, 2628-2636. 